\title{
Using Involvement Theory to Examine the Relationship between Undergraduate Participation in Extracurricular Activities and Leadership Development
}

\author{
Elizabeth A. Foreman, Ph.D. \\ Program Coordinator \\ College of Agriculture and Life Sciences \\ Iowa State University \\ 20 Curtiss Hall \\ Ames, IA 50011 \\ 515-294-4548 \\ bforeman@iastate.edu \\ Michael S. Retallick, Ph.D. \\ Associate Professor \\ Department of Agricultural Education \\ Iowa State University \\ 206 Curtiss Hall \\ Ames, IA 50011 \\ 515-294-4810 \\ msr@iastate.edu
}

\begin{abstract}
This study examined the relationship between extracurricular involvement and leadership outcomes among traditional-age college seniors in the College of Agriculture and Life Sciences at Iowa State University. We collected data related to quantitative (i.e., how much time a student spends on an activity) and qualitative (i.e., how focused the student is on the activity) aspects of involvement in extracurricular organizations. We measured leadership, as an outcome, using the individual values scale of the Socially Responsible Leadership Scale (SRLS-R2). The number of clubs in which a student participated and served as an officer was associated with higher leadership scores. We identified a threshold of involvement that suggests the optimum number of clubs or organizations to be actively involved in is three to four.
\end{abstract}

\section{Introduction}

A new generation of leaders is needed to address the changing issues facing local communities, build local partnerships, and assume leadership positions (Ewing, Bruce, \& Ricketts, 2009). To meet this need, many institutions of higher education have included leadership development in their mission statements (Astin \& Astin, 2000; Boatman, 1999) and implemented curricular experiences, classroom experiences, and out-of-classroom experiences to meet leadership outcomes. Astin (1999) suggests the concept of student involvement as a pedagogical theory to examine the student experience and learn more about how educational programs and policies are related to student achievement and development. 
Researchers and practitioners use involvement theory (Astin, 1999) as a theoretical framework for student involvement, including classroom, out-of-classroom, and curricular activities. Astin (1996) defined involvement as an investment of physical and psychological energy that occurs along a continuum and has both quantitative (e.g., time spent) and qualitative (e.g., amount of focus or depth) features. Astin described an involved student as one who "devotes considerable energy to studying, spends much time on campus, participates actively in student organizations, and interacts frequently with faculty members and other students" (p. 518). Astin's theoretical framework helps explain empirical knowledge about environmental influences on student development from a variety of psychosocial and learning pedagogies.

Research supports Astin's (1999) involvement theory. Pascarella and Terenzini (1991) found that the frequency and quality of students' participation in activities was associated with high educational aspirations, enhanced self-confidence, and increased interpersonal and leadership skills. Rubin, Bommer, and Baldwin (2002) concluded that an extracurricular index score that represents the number of clubs in which students were involved, officer status, and hours spent significantly predicted interpersonal skills such as communication, initiative, decision making, and teamwork. However, a gap in the literature exists between operationalization of involvement theory and research design.

\section{Conceptual Model and Literature Review}

The conceptual framework for this study was the collegiate leadership development model presented in Figure 1 (Foreman \& Retallick, 2012). The model has three constructs. Previous research has shown that the first two constructs, precollegiate and college experiences, contribute to leadership development in undergraduate students (Birkenholz \& Schumacher, 1994; Dugan \& Komives, 2007; Kezar \& Moriarty, 2000; Kimbrough, 1998; Layfield, Radhakrishna, \& Andreasen, 2000; Rubin et al., 2002; Schumacher \& Swan, 1993). The third construct, leadership development, is the outcome of the model and was conceptualized using the social change model (Higher Education Research Institute, 1996). The present study focused specifically on three components of this model: gender, out-of-classroom experiences, and individual values of leadership development. 


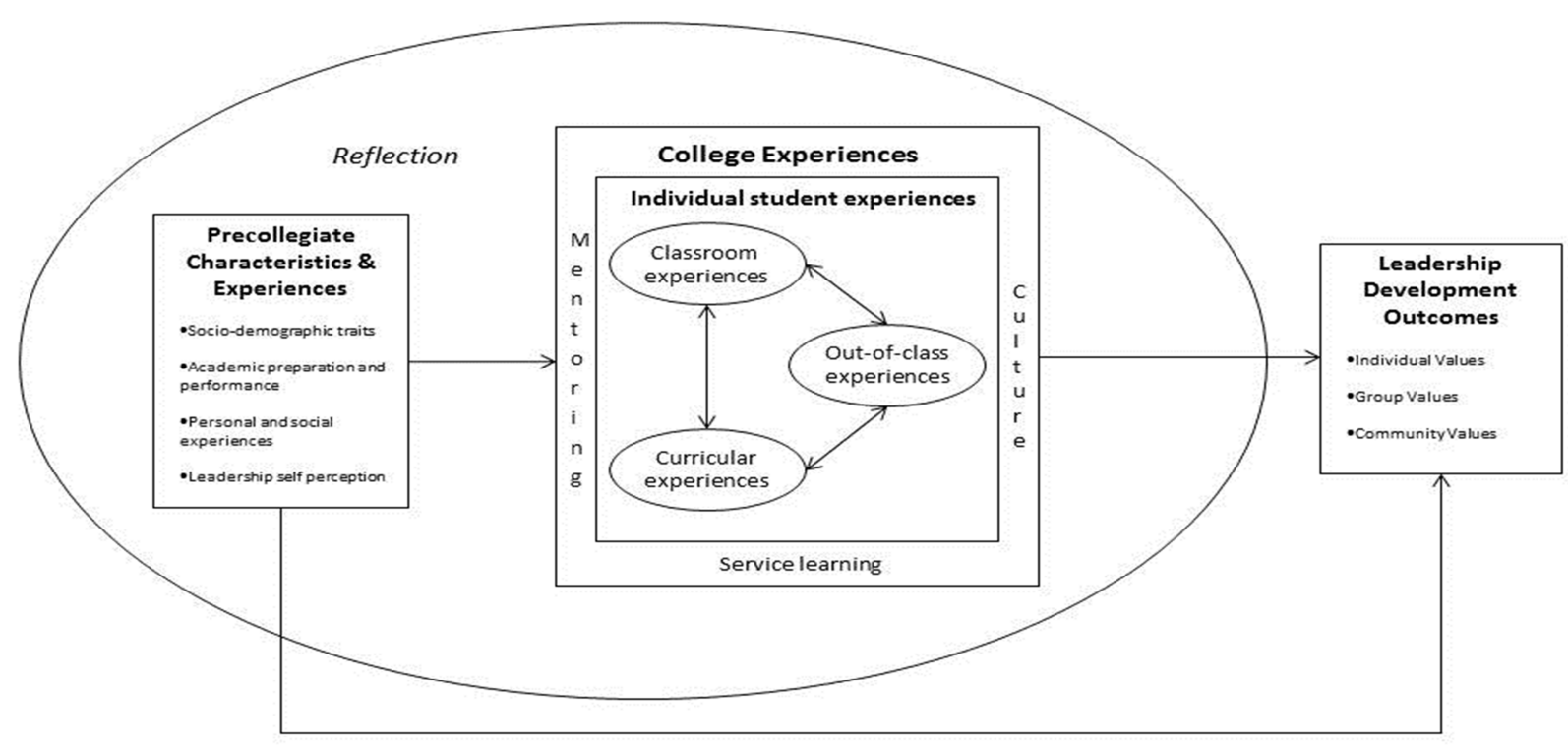

Collegiate Leadership Development Model (Foreman \& Retallick, 2012)

Figure 1. Collegiate leadership development model (Foreman \& Retallick, 2012).

Literature related to extracurricular participation, involvement theory, and leadership development was used to frame the current study.

\section{Extracurricular Participation}

Kuh and Umbach (2004) used data from the National Survey of Student Engagement and concluded that institutions should organize both in-class and out-of-class experiences to expose students to a variety of opportunities. Researchers have found empirical evidence that experiential learning is instrumental in the development of leadership skills. For example, Layfield et al. (2000) suggested that without meaningful opportunities to practice leading a group, students will not gain skills.

Researchers have found a wide variety of dependent variables positively related to participation in extracurricular clubs and organizations. Rubin et al. (2002) studied the relationship between involvement in extracurricular activities and interpersonal skills (e.g., oral communication, decision making, teamwork, conflict resolution, and initiative) and found that undergraduates who were involved in extracurricular activities had higher measures of interpersonal skills than those who did not participate. Similarly, students who participated in extracurricular clubs and organizations had higher scores in developing purpose (Cooper, Healy, \& Simpson, 1994), establishing and clarifying purpose (Martin, 2000; Stanford, 1992), and conflict resolution skills (Logue, Hutchins, \& Hector, 2005). College juniors who were members of student organizations scored higher than nonmembers on educational involvement, career planning, lifestyle planning, cultural participation, and academic autonomy (Cooper et al., 1994). 


\section{Involvement Theory}

Using longitudinal data focused on student persistence, Astin (1999) identified factors in the college environment that affected students' persistence in college. Involvement theory combines concepts found in the Freudian concept of cathexis which refers to psychological energy and the learning-theorist concept of vigilance or time-on-task which is a measurement of physical time spent on an activity. Since Astin (1999) introduced involvement theory, researchers and practitioners have used it to develop programs, modify curriculums, make administrative decisions, and conduct research. A discussion of the quantitative and qualitative features of involvement theory and how those relate to the undergraduate extracurricular experience follows.

Astin (1999) defined quantitative features of involvement as the physical amount of energy a student devotes to an activity. Research has examined the role of quantitative involvement features related to extracurricular experiences, including the number of clubs in which students participated (Dugan \& Komives, 2007), meeting participation (Winston et al., 1977), and the number of hours students spent participating in clubs and organizations (Astin 1999; Pascarella $\&$ Terenzini, 1991; Rubin et al., 2002). Each of these quantitative measures of involvement was related to increased leadership development. However, involvement in too many different types of organizations was negatively related to leadership outcomes (Dugan \& Komives, 2007).

Astin (1999) defined qualitative features of involvement as the psychological energy a student devotes to an activity. One example of a qualitative feature of extracurricular involvement is the positional leadership role experience. Research has found that students who served as an officer in a club or organization showed increased outcomes compared to those who did not serve as an officer. Serving as a club officer was related to increased decision-making skills (Rubin et al., 2002) and leadership skills (Dugan, 2006; Ewing et al., 2009). Cooper et al. (1994) found that students who served as an officer scored higher on scales related to developing purpose, educational involvement, life management, and cultural participation.

In contrast, some research did not indicate an increased benefit for students who held an office. Rubin et al. (2002) found no difference in initiative for officers. And, Foubert and Grainger (2006) found no increased psychosocial benefits for officers.

The literature includes few examples of studies that examined both quantitative and qualitative features of extracurricular involvement. Pascarella and Terenzini (1991) examined both the frequency and quality of students' participation and Rubin et al. (2002) studied an extracurricular index score that represented number of clubs, officer status, and hours spent. In both studies, the combination of frequency and quality of students' participation was associated with higher levels of various leadership and interpersonal skills.

Sometimes differentiating the relationship between quantitative and qualitative features is difficult. For example, Astin (1996) found that holding an office, public-speaking ability, leadership abilities, and interpersonal skills were all correlated to hours per week spent participating in student clubs and organizations. Serving as an officer has also been associated with spending more time participating in extracurricular clubs and organizations. Both 
independent variables were related to increased leadership development. Shertzer and Schuh (2004) suggested that students who held leadership positions in college were often given additional leadership development opportunities and that the increased skills attributed to serving as an officer may be associated with that additional training.

\section{Leadership Development}

Leadership development is the outcome construct of the collegiate leadership development model. The social change model, a widely cited model of student leadership in higher education (Haber \& Komives, 2009), describes leadership as a purposeful, collaborative, values-driven process (Dugan \& Komives, 2007). Its central principles - social responsibility and change for the common good - are assessed through eight core values that describe students' level of selfawareness and ability to work with others. The social change model views leadership as a process, not a position, and encourages leadership development in all participants, including those who hold formal leadership positions and those who do not. It promotes the values of equality, social justice, self-knowledge, personal empowerment, collaboration, citizenship, and service (Astin \& Astin, 1996).

\section{Problem Statement}

Astin (1999) identified three research topics that should be addressed to learn more about involvement:

- Identify the extracurricular activities in which a student participates and also the time and energy a student devotes to each activity.

- Examine the relationship between quality and quantity of involvement.

- Determine if there is an optimum level of involvement at which additional involvement does not produce desirable results.

Although Astin (1984) suggested an examination of the quantitative and qualitative aspects of involvement, little research has been published, especially in regard to students enrolled in colleges of agriculture and life sciences.

\section{Research Purpose and Questions}

The purpose of this study was to examine the relationships between undergraduate students' quantity and quality of involvement in extracurricular clubs and organizations and their leadership development. Six research questions guided this study:

- Does membership in an extracurricular club or organization influence individual values of leadership development?

- Does the number of extracurricular clubs and organizations in which a student participates in influence individual values of leadership development? 
- Does the amount of time a student participates in extracurricular clubs and organizations influence individual values of leadership development?

- Does serving as an officer in an extracurricular club or organization influence individual values of leadership development?

- Does the involvement index influence individual values of leadership development?

- Does gender influence individual values of leadership development?

\section{Methods}

This study was a part of a larger study designed to examine the role of undergraduate extracurricular participation in leadership development. We surveyed full-time undergraduate students classified as seniors in the College of Agriculture and Life Sciences at Iowa State University $(N=969)$.

\section{Instrumentation}

Pre-collegiate characteristics and experiences (e.g., gender) were obtained from university records. We did this to reduce the length of the online survey and increase the accuracy of demographic data. We used Qualtrics (Qualtrics Labs, Inc., Provo, UT) to administer the online survey.

Data about college experiences were collected using researcher-designed questions. We asked students if they participated in extracurricular organizations, competitive teams, and the Greek system, and used skip/display logic to customize the questions each student received. Students who reported involvement were then given a list of specific activities and organization including college-level clubs, judging or other competitive teams, student government, university-related clubs and organizations, social or recreational clubs and organizations, faithor religious-based organizations, community-based organizations, and the Greek system - and asked to select the ones in which they participated and indicate their level of involvement.

The leadership development construct was measured using the Socially Responsible Leadership Scale (SRLS-R2). The scale consists of 68 Likert-type items that make up eight separate scales which measure specific leadership constructs (individual values, group values, and community values) of the social change model. We used the individual values scale and the three subscales that make up the individual values scale for this study as shown in Figure 2.

Consciousness of self Being self-aware of the beliefs, values, attitudes, and emotions that motivate you to take action. Being mindful, or aware of your current emotional state, behavior, and perceptual lenses. 
Congruence

Acting in ways that are consistent with your values and beliefs. Thinking, feeling, and behaving with consistency, genuineness, authenticity, and honesty towards others.

Commitment

Having significant investment in an idea or person, both in terms of intensity and duration. Having the energy to serve the group and its goals. Commitment originates from within, but others can create an environment that supports an individual's passion.

Figure 2. Individual values subscales of the social change model (Wagner, 2006).

The Multi-Institutional Study of Leadership has used the SRLS-R2 with more than 60,000 students (National Clearinghouse for Leadership Programs, 2009) and found the instrument reliable. The Cronbach's alpha reliability values computed for this study for the SRLS-R2 individual values scale and consciousness of self, congruence, and commitment subscales were $.88, .80, .88$, and .87 , respectively.

A group of faculty and graduate students with expertise in undergraduate outcomes, extracurricular experiences, and leadership development reviewed the questionnaire for validity. They provided feedback about the content of the questionnaire based on the study's purpose and research questions. We also field-tested the questionnaire with junior students similar to the senior students in the study and then made changes in content, question format, and data collection procedures.

\section{Data Collection}

The Iowa State University Institutional Review Board approved the study. We modified Dillman's (2007) five-step data collection approach on the basis of suggestions from the expert panels. Because the student panels suggested that undergraduate students would view a prenotice as junk mail and be less likely to respond favorably to follow-up emails, we included the survey link, the purpose of the study, and information about general consent in the first email contact.

The distribution list obtained from the university registrar's office contained 969 names. We contacted students via e-mail up to five times over a 14-day period to reduce nonresponse. Those who responded were removed from the email list and not contacted again. This process resulted in 270 responses $(27 \%), 199$ of which were complete and usable $(20.5 \%)$.

Non-response error was controlled using two different methods. We used independent sample $t$ tests to compare early and late respondents, as suggested by Lindner, Murphy, and Briers (2001). According to this analysis, there were no differences in extracurricular involvement between early and late respondents. We also compared the demographics of survey respondents with 
demographics of the population by using data obtained from the university registrar's office. Females, students who entered the university directly from high school, and students with a higher grade point average were more likely to respond. Therefore, use caution when generalizing results beyond those who responded.

\section{Data Analysis}

Qualtrics (Qualtrics Labs, Inc., Provo, UT) automatically recorded survey responses as students completed the survey. Email addresses were used to match students' university record information with survey results. To ensure confidentiality, all identifying information was removed before data were analyzed using SPSS version 17.

Club and organization membership was a dichotomous variable. A $t$-test with membership as the independent variable and the individual values scale and three subscales as the dependent variables was used to determine the relationship between membership and individual leadership development.

The number of clubs and organizations a student participated in was recoded in four categories $(0,1-2,3-4,5-11$ clubs) An ANOVA with number of clubs and organizations as the independent variable and the individual values and subscales as the dependent variables was used to determine the relationship between number of clubs and individual leadership development.

Average hours per week spent in extracurricular clubs and organizations was a categorical variable with 20 possible answers recoded in four categories $(0-1,2-3,4-6,7$ or more hours per week). An ANOVA with hours per week as the independent variable and the individual values and subscales as the dependent variables was used to determine the relationship between time spent and individual leadership development.

Club leadership (i.e., serving as an officer) was a dichotomous variable. A $t$-test, with serving as an officer as the independent variable and the individual values and subscales as the dependent variables, was used to determine the relationship between club leadership and individual leadership development.

To measure a combined effect of qualitative and quantitative features of involvement, an extracurricular involvement index was calculated by adding the number of years a student indicated they were involved in a specific extracurricular activity and their highest level of involvement in that activity (ranging from $1=$ member to $5=$ state or national leadership). To measure the relationship between this construct and individual leadership (measured by the SRLS-R2 individual values scale), the involvement index was categorized into four approximately equal groups and used as the independent variable. Analysis of variance tests were calculated using involvement index as the independent variable and the individual values and subscales as the dependent variables. 
Gender information was collected from university records. Inferential statistics were calculated to determine the role of gender in the first four research questions.

\section{Results}

Ninety-one (45.7\%) males and 108 (54.3\%) females responded to the survey. Ninety-six percent of respondents were involved in an extracurricular activity, including $21 \%$ in the Greek system, $95 \%$ in extracurricular clubs and organizations, and $29 \%$ in competitive teams. When comparing gender using $t$-tests throughout this study, we found no differences on any of the leadership scales.

\section{Club Membership}

There were no statistical differences between members and nonmembers on the consciousness of self subscale. However as shown in Table 1, students who belonged to extracurricular clubs and organizations scored higher than nonmembers on the congruence subscale, commitment subscale, and individual values scale.

Table 1

t-test for Club Membership and Leadership Development (SRLS-R2)

\begin{tabular}{lllcc}
\hline & & & Mean & $S E$ \\
Dependent variable & $t$ & Sig. & difference & difference
\end{tabular}

\begin{tabular}{llllll}
\hline Consciousness of self & -1.69 & 77.36 & .095 & -1.13 & .67 \\
Congruence & -2.44 & 70.47 & $.017^{*}$ & -1.51 & .62 \\
Commitment & -2.14 & 73.33 & $.036^{*}$ & -1.11 & .52 \\
Individual values & -2.04 & 67.59 & $.045^{*}$ & -3.44 & 1.69 \\
\hline$* p \leq .05$. & & & &
\end{tabular}

\section{Number of Clubs}

The number of extracurricular clubs and organizations students were involved in ranged from 0 to $11(M=3.41, S D=2.44)$. Females $(M=3.91, S D=2.29)$ were involved in more clubs than males $(M=2.82, S D=2.48, t(197)=-3.198, p=.002)$. ANOVA results showed a significant relationship between the number of clubs and leadership development (Table 2). 
Table 2

Analysis of Variance for Number of Organizations and Leadership Development (SRLS-R2)

\begin{tabular}{|c|c|c|c|c|c|c|}
\hline $\begin{array}{l}\text { Dependent } \\
\text { variable }\end{array}$ & Group & $S S$ & $d f$ & $M S$ & $F$ & $p$ \\
\hline Consciousness & Between & 150.34 & 3 & 50.11 & 3.67 & $.013^{*}$ \\
\hline \multirow[t]{2}{*}{ of self } & Within & 2420.42 & 177 & 13.68 & & \\
\hline & Total & 2570.76 & 180 & & & \\
\hline \multirow[t]{3}{*}{ Congruence } & Between & 173.63 & 3 & 57.88 & 5.50 & $.001^{*}$ \\
\hline & Within & 1875.73 & 178 & 10.54 & & \\
\hline & Total & 2049.36 & 181 & & & \\
\hline \multirow[t]{3}{*}{ Commitment } & Between & 160.70 & 3 & 53.57 & 7.26 & $.000^{*}$ \\
\hline & Within & 1322.61 & 179 & 7.39 & & \\
\hline & Total & 1483.31 & 182 & & & \\
\hline Individual & Between & 1294.82 & 3 & 431.61 & 5.83 & $.001^{*}$ \\
\hline \multirow[t]{2}{*}{ Values } & Within & 12807.02 & 173 & 74.03 & & \\
\hline & Total & 14101.84 & 176 & & & \\
\hline
\end{tabular}

$* p \leq .05$

Because the ANOVA provided significant results, we conducted post hoc testing to compare and contrast mean differences between groups. A Tukey post hoc test revealed which levels of participation were associated with increased levels of individual leadership (Table 3 ). In most instances, the more clubs a student participated in, the higher the level of individual leadership development. However, at the highest level of involvement (participation in 5-11 clubs), the mean scores diminished compared with scores for students involved in 3-4 clubs.

Table 3

Tukey HSD Post hoc Results for Number of Clubs and Organizations and Leadership Development (SRLS-R2)

\begin{tabular}{llcccc}
\hline Test & $\begin{array}{c}\text { (I) Number of } \\
\text { clubs }\end{array}$ & $\begin{array}{c}\text { (J) Number of } \\
\text { clubs }\end{array}$ & $\begin{array}{c}\text { Mean } \\
\text { differences } \\
(\mathrm{I}-\mathrm{J})\end{array}$ & SE & $p$ \\
\hline Consciousness & 0 clubs & $1-2$ clubs & -1.82 & 2.53 & .890 \\
& & & & & \\
\hline
\end{tabular}




\begin{tabular}{|c|c|c|c|c|c|}
\hline \multirow{11}{*}{$\begin{array}{l}\text { of self } \\
\text { Tukey HSD }\end{array}$} & & 3-4 clubs & -7.58 & 2.48 & $.014^{*}$ \\
\hline & & 5-11 clubs & -5.64 & 2.53 & .120 \\
\hline & \multirow[t]{3}{*}{$1-2$ clubs } & 0 clubs & 1.82 & 2.53 & .890 \\
\hline & & 3-4 clubs & -5.76 & 1.64 & $.003 *$ \\
\hline & & 5-11 clubs & -3.81 & 1.71 & .120 \\
\hline & \multirow[t]{3}{*}{$3-4$ clubs } & 0 clubs & 7.58 & 2.48 & $.014 *$ \\
\hline & & 1-2 clubs & 5.76 & 1.64 & $.003 *$ \\
\hline & & 5-11 clubs & 1.95 & 1.63 & .633 \\
\hline & \multirow[t]{3}{*}{ 5-11 clubs } & 0 clubs & 5.63 & 2.53 & .120 \\
\hline & & $1-2$ clubs & 3.81 & 1.71 & .120 \\
\hline & & 3-4 clubs & -1.95 & 1.63 & .633 \\
\hline \multirow[t]{2}{*}{ Congruence } & \multirow[t]{3}{*}{0 clubs } & $1-2$ clubs & -.98 & .91 & .702 \\
\hline & & 3-4 clubs & -2.81 & .89 & $.010 *$ \\
\hline \multirow[t]{10}{*}{ Tukey HSD } & & 5-11 clubs & -2.49 & .90 & $.033^{*}$ \\
\hline & \multirow[t]{3}{*}{$1-2$ clubs } & 0 clubs & .98 & .91 & .703 \\
\hline & & 3-4 clubs & -1.83 & .62 & $.017 *$ \\
\hline & & 5-11 clubs & -1.51 & .63 & .087 \\
\hline & \multirow[t]{3}{*}{ 3-4 clubs } & 0 clubs & 2.81 & .89 & $.010^{*}$ \\
\hline & & $1-2$ clubs & 1.83 & .62 & $.017 *$ \\
\hline & & 5-11 clubs & .33 & .61 & .951 \\
\hline & \multirow[t]{3}{*}{ 5-11 clubs } & 0 clubs & 2.49 & .90 & $.033^{*}$ \\
\hline & & $1-2$ clubs & 1.51 & .64 & .087 \\
\hline & & 3-4 clubs & -.33 & .61 & .951 \\
\hline \multirow[t]{2}{*}{ Commitment } & \multirow[t]{3}{*}{0 clubs } & $1-2$ clubs & -.22 & .78 & .992 \\
\hline & & 3-4 clubs & -2.22 & .76 & $.021 *$ \\
\hline \multirow[t]{10}{*}{ Tukey HSD } & & 5-11 clubs & -1.97 & .77 & .056 \\
\hline & \multirow[t]{3}{*}{$1-2$ clubs } & 0 clubs & .22 & .78 & .992 \\
\hline & & 3-4 clubs & -1.20 & .51 & $.001 *$ \\
\hline & & 5-11 clubs & -1.75 & .53 & $.007 *$ \\
\hline & \multirow[t]{3}{*}{$3-4$ clubs } & 0 clubs & 2.22 & .76 & $.021 *$ \\
\hline & & $1-2$ clubs & 1.20 & .51 & $.001 *$ \\
\hline & & 5-11 clubs & .25 & .50 & .959 \\
\hline & \multirow[t]{3}{*}{ 5-11 clubs } & 0 clubs & 1.97 & .77 & .056 \\
\hline & & $1-2$ clubs & 1.75 & .53 & $.007 *$ \\
\hline & & 3-4 clubs & -.25 & .78 & .959 \\
\hline \multirow{3}{*}{$\begin{array}{l}\text { Individual } \\
\text { Values }\end{array}$} & \multirow[t]{3}{*}{0 clubs } & $1-2$ clubs & -1.82 & 2.53 & .890 \\
\hline & & 3-4 clubs & -7.58 & 2.48 & $.014 *$ \\
\hline & & 5-11 clubs & -5.63 & 2.53 & .120 \\
\hline \multirow[t]{6}{*}{ Tukey HSD } & \multirow{3}{*}{$1-2$ clubs } & 0 clubs & 1.82 & 2.53 & .890 \\
\hline & & 3-4 clubs & -5.76 & 1.64 & $.003 *$ \\
\hline & & 5-11 clubs & -3.81 & 1.71 & .120 \\
\hline & \multirow[t]{3}{*}{$3-4$ clubs } & 0 clubs & 5.58 & 2.48 & $.014^{*}$ \\
\hline & & $1-2$ clubs & 5.76 & 1.64 & $.003^{*}$ \\
\hline & & 5-11 clubs & 1.95 & 1.63 & .633 \\
\hline
\end{tabular}




\begin{tabular}{llrrr}
\hline $5-11$ clubs & 0 clubs & 5.63 & 2.53 & .120 \\
& $1-2$ clubs & 3.81 & 1.71 & .120 \\
& $3-4$ clubs & -1.95 & 1.63 & .633 \\
\hline
\end{tabular}

$* p \leq .05$.

\section{Time Spent in Extracurricular Clubs and Organizations}

The average amount of time students spent in extracurricular clubs and organizations ranged from 0 to 20 or more hours per week $(M=5.33)$. There were no differences in terms of gender $(p$ $\leq .575$ ). ANOVA results revealed no statistically significant relationships between time spent and individual leadership development.

\section{Positional Leadership Role}

One hundred forty-two students (71.4\%) served as an officer; 57 (28.6\%) did not. The Pearson chi-square test indicated no gender differences between students who served as an officer and those who did not $\left(\chi^{2}(1, N=199)=1.076, p=.30\right)$. Officers $(M=7.02, S D=4.69)$ spent more time per week involved in extracurricular clubs and organizations than students who were members only $(M=3.55, S D=4.39), t(196.957)=5.40, p=.000$. Students who served as an officer in a club or organization scored higher on the SRLS-R2 consciousness of self, commitment, and individual values scales. However, serving as an officer did not affect students' scores on the congruence scale (Table 4).

Table 4

t-test for Serving as an Officer and Leadership Development (SRLS-R2)

\begin{tabular}{lccccc}
\hline Dependent variable & $t$ & $d f$ & Sig. & $\begin{array}{c}\text { Mean } \\
\text { difference }\end{array}$ & $\begin{array}{c}S E \\
\text { difference }\end{array}$ \\
\hline $\begin{array}{l}\text { Consciousness of } \\
\text { self }\end{array}$ & -2.31 & 173.22 & $.022^{*}$ & -1.29 & .56 \\
Congruence & -1.72 & 167.48 & .087 & -.86 & .50 \\
Commitment & -3.07 & 168.24 & $.003^{*}$ & -1.28 & .42 \\
Individual values & -2.67 & 161.04 & $.008^{*}$ & -3.58 & 1.33 \\
& & & & & \\
\hline$* p \leq .05$.
\end{tabular}

\section{Involvement Index}

The extracurricular involvement index included number of activities, years of involvement, and highest level of involvement. In general, students with a higher involvement index score had higher scores on each of the SRLS-R2 scales examined (Table 5). However, this was not the case 
at the highest level of involvement, where the mean was less than the third level on all four leadership scales.

Table 5

Analysis of Variance for Involvement Index and Leadership Development (SRLS-R2)

\begin{tabular}{lrrrrrc}
\hline $\begin{array}{l}\text { Dependent } \\
\text { variable }\end{array}$ & \multicolumn{1}{l}{ Groups } & \multicolumn{1}{c}{$S$} & $d f$ & $M S$ & $F$ & $p$ \\
\hline Consciousness & Between & 169.48 & 3 & 56.49 & & \\
of self & Within & 2343.27 & 174 & 13.47 & 4.20 & $.007^{*}$ \\
& Total & 2512.75 & 177 & & & \\
Congruence & Between & 105.80 & 3 & 35.27 & 3.22 & $.024^{*}$ \\
& Within & 1914.78 & 175 & 10.94 & & \\
& Total & 2020.58 & 178 & & & \\
\hline Commitment & Between & 160.61 & 3 & 53.54 & 7.24 & $.000^{*}$ \\
& Within & 1302.03 & 176 & 7.40 & & \\
Individual & Total & 1462.64 & 179 & & & \\
Values & Between & 1167.56 & 3 & 389.19 & 5.24 & $.002^{*}$ \\
& Within & 12637.12 & 170 & 74.4 & & \\
\hline
\end{tabular}

$* p \leq .05$.

\section{Conclusions}

Students who responded to this survey were active in extracurricular clubs and organizations. Gender differences varied in this study. Females were involved in more extracurricular clubs and organizations than males. However, they did not spend more time per week in these activities and were not significantly more likely than their male counterparts to hold an office.

The number of clubs in which a student participated was associated with leadership outcomes for each of the four scales examined (i.e., consciousness of self, congruence, commitment, and individual values). These results indicate there is a threshold of participation at which increased participation is no longer associated with increased leadership. In fact, the highest level of participation was associated with lower levels of individual leadership for each scale.

Perhaps the most surprising finding of this study was that amount of time per week spent in extracurricular clubs and organizations was not related to increased leadership on any of the scales examined. This is inconsistent with our previous research (Foreman \& Retallick, 2012) in which we found that students who spent more time participating in extracurricular activities had higher scores on both the SRLS-R2 group and SRLS-R2 omnibus scales. Other researchers have 
examined the amount of time students participated in extracurricular activities (Astin 1999; Pascarella \& Terenzini, 1991; Rubin et al., 2002) and students' meeting attendance (Winston et al., 1977) and concluded that quantitative measures of involvement were related to leadership development.

Holding an office in an organization can enhance the richness and magnitude of learning experiences and personal development during the college years (Astin, 1984). In this study, students who held a positional leadership role in a club or organization spent more time involved in clubs and organizations and scored significantly higher on the consciousness of self, commitment, and individual values scales. This is consistent with findings of previous researchers who showed that serving as a club officer was related to increased leadership development (Ewing et al., 2009) and decision making (Rubin et al., 2002). Dugan (2006) found that students who served as positional leaders scored higher on the SRLS-R2 group values scale and SRLS-R2 societal values scale. However, students in the present study who held a positional leadership role did not score higher on the congruence scale than those who did not hold an office. This finding supports previous research that found no increased benefit in terms of psychosocial development for students who served as officers in extracurricular clubs or organizations over students who were members (Foubert \& Grainger, 2006).

The involvement index was related to each of the leadership scales examined (individual values, consciousness of self, congruence, and commitment). The results indicate a law of diminishing returns. Higher levels of leadership were found at each increasing level of involvement except the highest level, at which leadership decreased.

\section{Implications and Recommendations}

Leadership development is an important outcome of the college student experience. Results of this study are consistent with previous research (Birkenholz \& Schumacher, 1994; Ewing et al., 2009) on the importance of participating in extracurricular clubs and organizations. Involvement in these activities has a strong relationship with leadership development, and institutions should include the role of extracurricular activities as they develop action plans for reaching leadership development outcomes. Astin (1984) suggested that institutional policies be evaluated in terms of the degree to which they increase or reduce student involvement.

Astin (1984) indicated a need for research on the relationship between quality and quantity of involvement. In regard to quantity (i.e., time spent), findings of this study are inconsistent with previous research, particularly a study that used the same students but the group values scale of the SRLS-R2 (Foreman \& Retallick, 2012). Additional research is needed to determine if amount of time spent participating in extracurricular clubs and organizations is more likely to be related to group values than individual values.

Though time spent (a quantitative measure) was not associated with increased leadership development, serving as an officer (a qualitative measure) was. Results of this study suggest that quality of involvement may be more important than time spent participating. Shertzer and Schuh (2004) suggested that students who hold leadership positions in college are often given more 
leadership development opportunities than students who are members only. Therefore, the increased skills often attributed to serving as an officer may actually be associated with the additional training that officers receive. On the basis of these findings, we recommend increasing the amount of leadership training and opportunities for all students in extracurricular clubs and organizations.

Astin (1984) proposed that there might be a desirable limit of involvement - a point at which additional involvement does not produce desirable results and may be detrimental. Results of this study support that assumption. For two relationships in this study (i.e., number of clubs and leadership development; involvement index and leadership development), there seemed to be a threshold at which increased involvement no longer had a positive effect. This trend suggests that when the quantitative measures of involvement exceed the desirable limit then the quality of the involvement is less and the positive outcomes are reduced.

A limitation of this study is that data were collected at one college of agriculture and life sciences at a fairly homogeneous institution. In spite of this limitation, the analysis offers insights for other institutions that aspire to increase student leadership outcomes. It is also noteworthy that a high percentage of students who completed the survey were involved in extracurricular clubs and organizations. Ninety-six percent of respondents indicated they were involved in an extracurricular activity. Though this seems high compared with involvement at the university where $33 \%$ of seniors spent at least six hours per week participating in cocurricular activities such as student organizations and intramural sports (Institutional Research, 2011), the culture of this college encourages extracurricular involvement.

Faculty and staff need to work with student leaders to create meaningful opportunities and encourage students to participate. Involvement theory provides some suggestions for these experiences. However, additional research is needed to identify specific characteristics or activities of extracurricular involvement that are most likely to increase leadership outcomes.

\section{References}

Astin, A. W. (1984). Student involvement: A developmental theory for higher education. Journal of College Student Personnel, 25, 297-308.

Astin, A. W. (1996). Involvement in learning revisited: Lessons we have learned. Journal of College Student Development, 37, 123-134.

Astin, A. W. (1999). Student involvement: A developmental theory for higher education. Journal of College Student Personnel, 40, 518-529.

Astin, A. W., \& Astin, H. S. (2000). Leadership reconsidered. Engaging higher education in social change. Battle Creek, MI: W. K. Kellogg Foundation.

Astin, H. S., \& Astin, A. W. (1996). A social change model of leadership development guidebook (version 3). Los Angeles: Higher Education Research Institute, University of 
California, Los Angeles.

Birkenholz, R. J., \& Schumacher, L. G. (1994). Leadership skills of college of agriculture graduates. Journal of Agricultural Education, 35(4), 1-8.

Boatman, S. A. (1999). The leadership audit: A process to enhance the development of student leadership. NASPA Journal, 37, 325-336.

Cooper, D. L., Healy, M. A., \& Simpson, J. (1994). Student development through involvement: Specific changes over time. Journal of College Student Development, 35, 98-102.

Dillman, D. A. (2007). Mail and Internet surveys: The tailored design method (2 ${ }^{\text {nd }}$ ed.). New York: John Wiley and Sons.

Dugan, J. P. (2006). Involvement and leadership: A descriptive analysis of socially responsible leadership. Journal of Student Development, 47, 335-343.

Dugan, J. P., \& Komives, S. R. (2007). Developing leadership capacity in college students: Findings from a national study. A Report from the Multi-Institutional Study of Leadership. College Park, MD: National Clearinghouse for Leadership Programs.

Ewing, J. C., Bruce, J. A., \& Ricketts, K. G. (2009). Effective leadership development for undergraduates: How important is active participation in collegiate organizations? Journal of Leadership Education, 7, 118-131.

Foreman, E. A., \& Retallick, M. S. (2012). Undergraduate involvement in extracurricular activities and leadership development in College of Agriculture and Life Sciences students. Journal of Agricultural Education, 53(3), 111-123. doi:10.5032/jae.2012.0311

Foubert, J. D., \& Grainger, L. U. (2006). Effects of involvement in clubs and organizations on the psychosocial development of first-year and senior college students. NASPA Journal, 43, 166-182.

Haber, P., \& Komives, S. R. (2009). Predicting the individual values of the social change model of leadership development: The role of college students' leadership involvement experiences. Journal of Leadership Education, 7, 133-166.

Higher Education Research Institute (1996). A social change model of leadership development: Guidebook version III. College Park, MD: National Clearinghouse for Leadership Programs.

Institutional Research (2011). Institutional Research. Retrieved from http://www.ir.iastate.edu/

Kezar, A., \& Moriarty, D. (2000). Expanding our understanding of student leadership development: A study exploring gender and ethnic identity. Journal of College Student 
Development, 41, 55-69.

Kimbrough, W. M. (1998). The impact of membership in black Greek-letter organizations on black students' involvement in collegiate activities and their development of leadership skills. Journal of Negro Education, 67(2), 96-105.

Kuh, G. D., \& Umbach, P. D. (2004). College and Character: Insights from the national survey of student engagement. New Directions for Institutional Research, 2004: 37-54. doi:10.1002/ir.108

Layfield, K. D., Radhakrishna, R. B., \& Andreasen, R. J. (2000). Self-perceived leadership skills of students in leadership programs in agriculture courses. Journal of Southern Agriculture Research, 50(1), 62-68.

Linder, J. R., Murphy, T. H., \& Briers, G. E. (2001). Handling nonresponse in social science research. Journal of Agricultural Education, 42(4), 43-53. doi:10.5032/jae.2001.04043

Logue, C. T., Hutchins, T. A., \& Hector, M. A. (2005). Student leadership: A phenomenological exploration of postsecondary experiences. Journal of College Student Development, 46(4), 393-408.

Martin, L. M. (2000). The relationship of college experiences to psychosocial outcomes in students. Journal of College Student Development, 41, 294-303.

National Clearinghouse for Leadership Programs. (2009). Socially Responsible Leadership Scale [survey]. College Park, MD: Author.

Pascarella, E., \& Terenzini, P. T. (1991). How college affects students. San Francisco: JosseyBass.

Qualtrics Labs, Inc. software, version [19,973] of the Qualtrics Research Suite [online survey program]. Provo, UT: Author. Retrieved from http://www.qualtrics.com

Rubin, R. S., Bommer, W. H., \& Baldwin, T. T. (2002). Using extracurricular activity as an indicator of interpersonal skill: Prudent evaluation or recruiting malpractice? Human Resource Management, 41, 441-454.

Schumacher, L. G., \& Swan, M. K. (1993). Need for formal leadership training for students in land-grant college of agriculture. Journal of Agricultural Education, 34(3), 1-9. doi:10.5032/jae.1993.03001

Shertzer, J. E., \& Schuh, J. H. (2004). College student perceptions of leadership: Empowering and constraining beliefs. National Association of Student Personnel Administrators Journal, 42(1), 111-131. 
Stanford, S. W. (1992). Extracurricular involvement and development among undergraduate student leaders. College Student Affairs Journal, 12, 17-24.

Wagner, W. (2006). The social change model of leadership: A brief overview. Concepts \& Connections, 15(1), 9.

\section{Author Biographies}

Dr. Elizabeth A. Foreman is a Program Coordinator for the College of Agriculture and Life Sciences at Iowa State University. She works with undergraduate recruitment and advises the college ambassador program. Dr. Foreman's research focuses on the undergraduate recruitment experience and collegiate leadership development. Her specific interest is examining the role of classroom experiences, curricular experiences, and out-of-classroom experiences in leadership development. She earned her doctorate in Agricultural Education, a master's in Human Development, and a bachelor's in Child, Parent, and Community Services from Iowa State University.

Dr. Michael S. Retallick is an Associate Professor in the Department of Agricultural Education and Studies at Iowa State University. He teaches courses and conducts research in the area of experiential learning as it relates to formal education at both the secondary and higher education levels. He earned a doctorate in Agricultural Education from Iowa State University, a master's in Agribusiness from Kansas State University, and a bachelor's degree from the University of Wisconsin-Platteville. 